\title{
A Study of Dialectology on Javanese "Ngoko" in Banyuwangi, Surabaya, Magetan, and Solo
}

\author{
Erlin Kartikasari; Kisyani-Laksono; Agusniar Dian Savitri; Diah Yovita Suryarini \\ Universitas Wijaya Kusuma Surabaya, Indonesia; Universitas Negeri Surabaya, Indonesia \\ Corresponding Author: erlinkartikasari@uwks.ac.id
}

\begin{abstract}
Dialectology study on Javanese language in Banyuwangi, Surabaya, Magetan and Solo is significant as it reveals the lexical and phonological differences of Javanese "ngoko" in the four areasresearched. The areas were chosen due to the following reason; Banyuwangi is located in the eastern tip of Java Island and directly borders the islands of Bali and Madura, Surabaya is the capital of East Java province as well as a metropolitan city, Magetan is located in the western tip of East Java Province which is directly adjacent to Central Java Province, and Solo is the center of Javanese culture in Central Java. The focus of this research is to calculate the number of lexical and phonological differences of Javanese "ngoko" in Banyuwangi, Surabaya, Magetan and Solo. This research uses quantitative researchwith (the or a) descriptive method. The data of the research is Javanese "ngoko". The instrument is Nothofer questionnaires modified by Kisyani by developing Swadesh's list into 829 words/phrases. The results of the research reveal(1) the largest number of Javanese "ngoko" lexical is found in Solo while theleast were found in Surabaya. The lexical differences of Javanese "ngoko" in Banyuwangi, Surabaya, Magetan, and Solo resulted in one utterance, two dialects and four subdialects, (2)19 patterns of phonological differences in Javanese "ngoko" were found. Finally, the phonological differences of Javanese "ngoko" in Banyuwangi, Surabaya, Magetan, and Solo resulted in four utterances.
\end{abstract}

Keywords: dialectology; Javanese "ngoko"; lexical differences; phonological differences; dialect; subdialect; utterance

\section{INTRODUCTION}

Javanese language is a language used by the Javanese community that reflects ( $\mathrm{a} / \mathrm{the}$ ) high dignity of Javanese people. Javanese language has its own identity that makes it different from other regional languages. Based on the dialectology study, Javanese is the language with the most speakers compared to other local languages in Indonesia. Grimes 2000 (Kisyani, 2009: 20) stated that there are 6,703 languages in the world. The most significant distribution area exists in Asia, which contains 2,165 languages (32\%). Asia is followed byAfrica with 2,011 languages (30\%), Pacific with 1,302 languages (19\%), America with 1,000 languages (15\%), and Europe with 225 languages (3\%). Among the 6,703 languages in the world, Javanese is the $11^{\text {th }}$ most commonly spoken language (75.5 million), Sundanese is the $34^{\text {th }}(27$ million), Malay is the $54^{\text {th }}$ (17.6 million), Indonesian is the $56^{\text {th }}(17,050,000)$ and Madurese is the $69^{\text {th }}$ $(13,694,000)$.

The Grimes data (2000) claimed that Javanese is the language that very much taken in to account in the world. Javanese is a source of pride for Indonesian people, especially for the Javanese community who isthe owner and heir of the language. The fact that Javanese is the ranked $11^{\text {th }}$ in the world is significant, especially because Javanese language out numbers the Indonesian language, which is 56th,far below Javanese. However, there are some flaws with the Grimes data, as it does not clearly explain the percentage of Javanese language usage in detail in 
each "unggah-ungguh" (level of politeness). Javanese language has three "unggah-ungguh" languages, namely Javanese "ngoko", "madya", and "krama".

The following data is the Javanese language development in 2008 taken from SIL (Formerly known as Summer Institute of Linguistics-a US based organization whose main purpose is to study, develop and document languages) in Wikipedia. This information presents the rank of languages with the largest number of speakers in Indonesia as follows:

Table 1. Language Rank in Indonesia

\begin{tabular}{|c|l|l|}
\hline No. & Language & Rank \\
\hline $\mathbf{1}$ & Javanese & $\begin{array}{l}12^{\text {th }} \text { rank in the world: } 75.6 \\
\text { million speakers }\end{array}$ \\
\hline $\mathbf{2}$ & Sundanese & $39^{\text {th }}$ rank: 27 million \\
\hline $\mathbf{3}$ & Indonesian & $\begin{array}{l}50^{\text {th }}: 17.1 \text { million }(140 \text { million } \\
\text { as a second language })\end{array}$ \\
\hline $\mathbf{4}$ & Madurese & $61^{\text {st }}: 13.7$ million \\
\hline $\mathbf{5}$ & Minangkabau & $95^{\text {th }}: 6.5$ million \\
\hline $\mathbf{6}$ & Batak & $99^{\text {th }}: 6,2$ million \\
\hline $\mathbf{7}$ & Balinese & $124^{\text {th }}: 3.8$ million \\
\hline $\mathbf{8}$ & Bugis & $\begin{array}{l}129^{\text {th }}, \text { as a second language: } \\
\text { below } 4 \text { million }\end{array}$ \\
\hline $\mathbf{9}$ & Aceh & $147^{\text {th }}: 3$ million \\
\hline $\mathbf{1 0}$ & Betawi/creol & $156^{\text {th }: 2.7 \text { million }}$ \\
\hline $\mathbf{1 1}$ & Sasak & $175^{\text {th }: 2.1 \text { million }}$ \\
\hline $\mathbf{1 2}$ & Makassar & $\begin{array}{l}196^{\text {th }}(\text { as a second language: } 2 \\
\text { million })\end{array}$ \\
\hline $\mathbf{1 3}$ & Lampung & $\begin{array}{l}205^{\text {th }} \text { (as a second language: } \\
\text { below } 1.5 \text { million })\end{array}$ \\
\hline $\mathbf{1 4}$ & Rejang & $258^{\text {th }: \text { below } 1 \text { million }}$ \\
\hline & & \\
\hline
\end{tabular}

(SIL in Wikipedia, 2008)

The decline in the number of Javanese speakers from the $11^{\text {th }}$ to the $12^{\text {th }}$ rank put the continuity of the Javanese language at risk. But behind the down grade, there was a proud fact that there was an increase in the number of Javanese speakers in the world from 75.5 million speakers in 2000 to 75.6 million speakers in 2008, an increase of 0.1 million speakers during a period of approximately eight years. This, of course, is a positive step for the existence of the Javanese language in the world because the Javanese language was still the choice of the community in Central andEast Java to communicate, although the data did not explain precisely the number of speakers in each of the "unggah-ungguh" at the level of Javanese"ngoko", "madya", and "krama".

Javanese language presents a fascinating case study asit has a vast amount of native speakers. Purwo in 2000 (Kisyani, 2009: 18) stated that from various languages of the world, the number of languages which had been studied was as follows:

Table 2. Number of Languages Studied

\begin{tabular}{|c|c|c|c|}
\hline 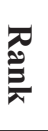 & $\begin{array}{c}\text { Number of } \\
\text { Languages } \\
\text { Studied }\end{array}$ & Description & Example \\
\hline $\mathbf{A}$ & $40-50$ & $\begin{array}{l}\text { Have been researched } \\
\text { adequately and } \\
\text { deeply, almost all the } \\
\text { details }\end{array}$ & $\begin{array}{l}\text { English } \\
\text { Germany }\end{array}$ \\
\hline B & 600 & $\begin{array}{l}\text { Have been researched } \\
\text { adequately and } \\
\text { deeply, only some of } \\
\text { the details }\end{array}$ & $\begin{array}{c}\text { Indonesian } \\
\text { Tagalog }\end{array}$ \\
\hline C & 1000 & $\begin{array}{l}\text { lessin-depth research } \\
\text { has been carried } \\
\text { out;i.e. only its } \\
\text { grammar,which is in } \\
\text { the form of "sketch" }\end{array}$ & Javanese \\
\hline D & $2000-3000$ & $\begin{array}{l}\text { Have been researched } \\
\text { inadequately, the } \\
\text { description is simple, } \\
\text { and there is a list } \\
\text { of words (not yet } \\
\text { forming a dictionary) }\end{array}$ & \\
\hline
\end{tabular}

Based on the table made by Purwo (2000), English and German were in rank A, so it was less likely to research both languages because they had already been studied adequately and intensely. Indonesian and Tagalog, which occupy rank B, stillare still possible to examine, as they still exist and despite adequate and in-depth examination, the details were only partially discussed. The Javanese language was in rank $\mathrm{C}$ which means less in depth research has been conducted, namely only the Javanese grammar in the form of "sketches" had been researched.Thus, it was still possible to investigate further, including the Javanese "ngoko" which is part of Javanese "unggahungguh."

This research used four research locations. They were Banyuwangi, Surabaya, Magetan, and Solo. Banyuwangi district was chosen because it is located in the eastern tip of Java island. Its strategic 
location is directly adjacent to Madura and Bali Island making the social, culture, and language mix in Banyuwangi very obvious. Banyuwangi also has its distinctive feature of Osing language, the people of Banyuwangi always feel proud of their language. Accordingly Osing is the language that isthe pride of the Banyuwangi tribe. The preservation of the Javanese language in Banyuwangi needs to be questioned because the mixing of Madurese and Balinese language with the Osing language as a local pride has made the displace the Javanese "ngoko" in Banyuwangi.

Surabaya was chosen because Surabaya is the capital of East Java Province. Also, Surabaya is a major port and commercial trading center in eastern Indonesia and is now one of the largest cities in Southeast Asia.Alot of domestic and foreign investors are investing in Surabaya to build companies, factories, and malls. This causes vast urbanization from various regions in Surabaya hoping to get a job. Those existence of people from different areas either from Indonesia or abroad, result invariants of language from many languages, including Madurese, Chinese, Arabic, English and other languages that can shift the existence of Javanese language in Surabaya city.

Magetan was chosen because Magetan is one of the regencies located at the western tip of East Java Province which borders directly with the Central Java Province. The Central Java Province has two Monarchies that are still recognized inIndonesia. The two monarchies are Kraton Surakarta Hadiningrat located in Solo and Kraton Yogyakarta Hadiningrat located in Yogyakarta. Both Kraton are still very attached to Javanese language and culture. The close distance of Magetan with the two monarchies is expected to bring positive influence to the existence of Javanese language towards Magetan society.

Solo is one of the two central cultural cities in Central Java. The other city is Yogyakarta. Solo is the center of Javanese language because there is Kraton Surakarta Hadiningrat, which is considered to be the center of Javanese language guidance. The Javanese language in Solo is the standard Javanese language that is used as a guide for Javanese in other areas. Therefore, the existence of the Javanese language in this city needs to be examined as a comparison with Javanese language in other research areas.

This research started by examined the existence of Javanese 'ngoko' in Banyuwangi, which is located at the eastern tip of Java island, heading west to
Surabaya as the center of East Java government, then heading west again to Magetan as the border city of East and Central Java, then stop in Solo which is believed by Javanese society as the center of Javanese language started to be questioned. The questions are, 'Is the vocabulary of Javanese "ngoko" increasing or reducing when it goes to western area? and, "does Javanese "ngoko" in Banyuwangi, Surabaya, Magetan, and Solo have differences?' The current research considers these two questions in researching Javanese language in Banyuwangi, Surabaya, Magetan, and Solo.

Several other studies relevant to this research were done by Toha (2013) who investigated Isolects in Aceh Tamiang District of Aceh Province and found the conclusion that Malay Tamiang dialect has 9 vowel sounds, namely [i, I, e, |, E, a, O, u, and U], 2 diphthongs, namely [aw and Uy] and 19 consonants, namely[b, c, d, h, g, j, k, l, m, n, p, R, s, t, y, w, G, n, dan Ö]. Kurniati and Mardikantoro (2010) examined The Pattern of Javanese Language Variation (Sociodialectology Study in Society in Central Java) and found out that variation of Javanese language in Central Java can occur in the areas of phonology, lexicon, the tendency of what to become "krama", the tendency of what to become "ngoko", and morphemic processes. Social factors in the form of education, age, and work also have an effect on the linguistic form of Javanese language.Kisyani-Laksono (2004) wrote about this in their paper titled, The Javanese language in Northern East Java and Blambangan. The research concluded that: (1) there were 44 "krama" responses that synchronically appeared to use Indonesian language, but if they are observed, not all "krama" is derived from the Indonesian language. Some came from Old Javanese language, Javanese dictionary, and Malay language (2) whichwas regarded as a form of "krama" in a region but is not necessarily regarded as a form of "krama" elsewhere, (3) In general, the "krama" form in the observation area (OA) was usually longer than the "ngoko" form. KisyaniLaksono (2000) discussed this in their paper titled Javanese Isolect language in Tuban and Bojonegoro. The research concludes that first, there was a different use of isolect among the observation area of 5 places of Samin community and other observation area; the difference was due to the proximity of the observation area 5 with Ngawi District whose isolect refers to the Solo-Yogya dialect in Central Java. And second, there were innovative forms in most of the observation area. Kisyani-Laksono (1998) studied The Javanese 
Isolect language in Keduwung, Tengger. The research concluded that there were different isolects between "Keduwung Atas" and "Keduwung Bawah", the differences were caused by: (1) difficult relations between the two regions, (2) "Keduwung Atas" had more relic elements than "Keduwung Bawah", thus, the "Keduwung Atas" region is a so-called Javanese language relic.

\section{METHOD}

The current research on Javanese "ngoko" in Banyuwangi, Surabaya, Magetan and Solo is quantitative research with descriptive method. The calculation of Javanese "ngoko" responses in Banyuwangi, Surabaya, Magetan, and Solo used the dialectometry method. Dialectometry is a measure used to see 'how difference there is in the places being studied' by comparing data obtained from the locations (Mahsun, 1995: 118). Research subjects were adults who were natives of Banyuwangi, Surabaya, Magetan, and Solo and had B1 of Javanese language. The adult criteria restrictions based on Law number 01 of 1974 on Marriage is 1) aged 17-40 years, 2) married, and 3) physically and mentally healthy. The linguistic data is the data of Javanese "ngoko"of adults in Banyuwangi, Surabaya, Magetan, and Solo. The data was obtained from a list of questions developed by Nothofer and modified by Kisyani by developing Swadesh's list into 829 words/phrases covering 20 meaning areas. A basic map of the research is taken from pffanon.wikia.com. Here is the map of the research location.

Figure 1. Research sites

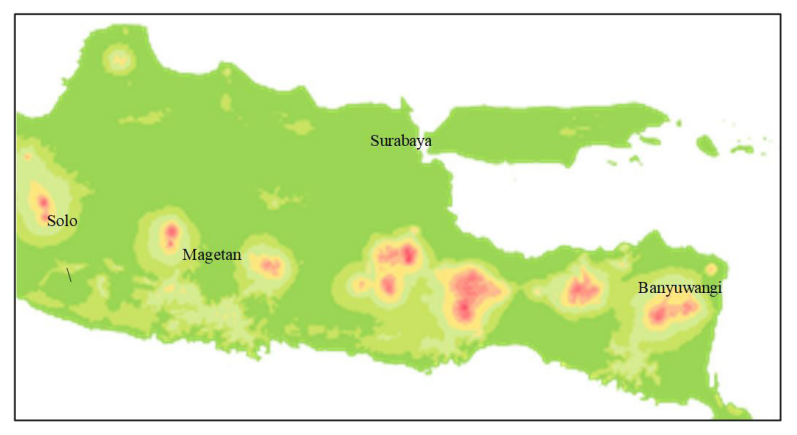

At each of the research sites, two observation areaswere selected, namely the city and the suburbs. The city of Banyuwang consists of two observation areas as well as Surabaya, Magetan, and Solo. So the total number of observation areas in this study is eight observation areas. Here are the observation areas in Banyuwangi, Surabaya, Magetan, and Solo.

Figure 2. Observation Area

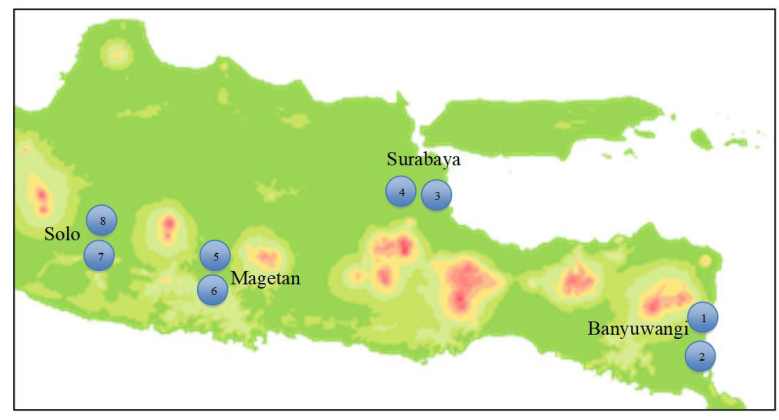

Before performing the calculation using the dialectometry method, mapping of the observation areas is d one based on dialectometry triangle and polygon map. Indetermining the triangle and polygon dialectometry, some rules must be considered. The rules are as follows:

1. The compared observation areas is only observation areas which may directly communicate based on their location.

2. Each observation areas that may directly communicate with one another is connected with a line so that a triangle with various shapes are obtained.

3. The lines on the dialectometric triangle cannot be intersected; it is better to choose one possibility which is located closer than the others (Mahsun, 1995: 119).

Figure 3. Dialectometry Triangle

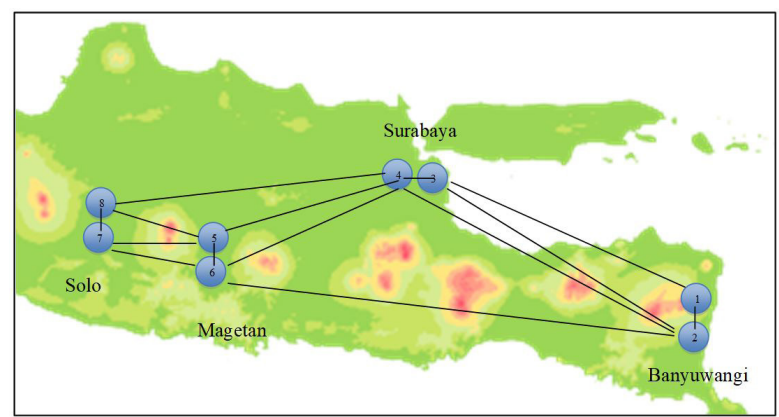

After making the dialectometry triangle map, the researcher made a dialectometry polygon map. Dialectometry polygon map is used more forvisualizing the boundaries between observation areas than the dialectometry triangle map because 
the dialectometry triangle map only connects the observation areas, while the dialectometry polygon map separates them.

Figure 4. Dialectometry Polygon

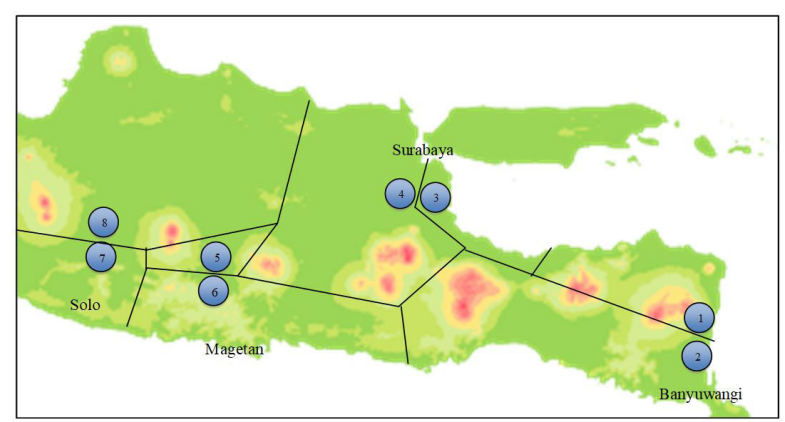

Based on the dialectometry triangle and polygon map, the pairs of observation areas were determined to decide the lexical and phonological differences in the "ngoko" Javanese language. The following observation areas pairs were compared:

Table 3. Comparable OA

\begin{tabular}{|c|c|}
\hline No. & OA Pairs \\
\hline 1 & $1: 2$ \\
\hline 2 & $1: 3$ \\
\hline 3 & $2: 3$ \\
\hline 4 & $2: 4$ \\
\hline 5 & $2: 6$ \\
\hline 6 & $3: 4$ \\
\hline 7 & $4: 5$ \\
\hline 8 & $4: 6$ \\
\hline 9 & $4: 8$ \\
\hline 10 & $5: 6$ \\
\hline 11 & $5: 7$ \\
\hline 12 & $5: 8$ \\
\hline 13 & $6: 7$ \\
\hline 14 & $7: 8$ \\
\hline
\end{tabular}

After the comparable pair of observation areas were determined using dialectometry triangle and polygon guidance, we calculated the number of lexical and phonological differences of Javanese "ngoko" in Banyuwangi, Surabaya, Magetan, and Solo using the dialectometric formula.

\section{DISCUSSION}

\section{The Calculation of Total Lexical Differences of Javanese "Ngoko"}

Mahsun (1995: 54) stated that differences in lexical happened when the lexemes used to express a similar meaning do not come from a single pretext etymon. All lexical differences were always in variations. Nadra and Reniwati (2009: 28) suggested that lexical difference or lexical variations were language variations or differences in the lexical field. A difference was called a lexicon distinction if the lexicons used to express a meaning came from different etymons. In determining lexicon difference, phonological and morphological differences were considered absent. In other words, phonological and morphological differences were ignored in deciding lexicon differences.

The calculation of the total lexical difference of Javanese "ngoko" in Banyuwangi, Surabaya, Magetan, and Solo used dialectometric formula. The data collection of Javanese "ngoko" in Banyuwangi, Surabaya, Magetan, and Solo was done by using Nothofer's modified questionnaire list of 829 words/ phrases including 20 meaning areas. The 20 meaning areas were: (1) number, (2) size, (3) season and time, (4) human body parts, (5) greetings and references, (6) kinship terms, (7) clothing and jewelry, (8) occupations, (9) animals, (10) animal body parts, (11) plants: fruit parts and their processed products, (12) nature, (13) houses and their parts, (14) tools, (15) disease and medicine (16) direction and guide, (17) activity, (18) nature, (19) color and odor, and (20) flavors.

The lexical data of Javanese "ngoko" in Banyuwangi, Surabaya, Magetan, and Solo indicated that not all words or phrases presented to the research subjects were responded in Javanese "ngoko." Of the 829 words/phrases asked to the adults in all observation areas somewere answered in Bahasa Indonesia. This was caused by various factors, including geographical, educational, and social, which causedthe subjects of research on each OA to begin to detach from Javanese "ngoko". Zero represents identical subjects' responses in all observation areas, so they were not described. The following is the total lexical Javanese "ngoko" on each observation areas in Banyuwangi, Surabaya, Magetan, and Solo.

Based on the lexical calculation of Javanese "ngoko" in Banyuwangi, Surabaya, Magetan, and Solo, the following division groups were obtained: 
Table 4. The Number of Javanese "ngoko" Lexical in Banyuwangi, Surabaya, Magetan and Solo

\begin{tabular}{|c|c|c|c|c|c|c|c|}
\hline \multirow{2}{*}{ No } & \multirow{2}{*}{ No. OA } & \multicolumn{7}{|c|}{ Javanese } & \multirow{2}{*}{ Total } \\
\cline { 3 - 8 } & & $\begin{array}{c}\text { Javanese } \\
\text { "ngoko" }\end{array}$ & Indonesian & Krama & Osing & Zero & \\
\hline 1 & 1 & 758 & 14 & - & 50 & 7 & 829 \\
\hline 2 & 2 & 757 & 23 & - & 29 & 20 & 829 \\
\hline 3 & 3 & 736 & 65 & - & - & 28 & 829 \\
\hline 4 & 4 & 732 & 69 & - & - & 28 & 829 \\
\hline 5 & 5 & 791 & 16 & - & - & 22 & 829 \\
\hline 6 & 6 & 791 & 16 & - & - & 22 & 829 \\
\hline 7 & 7 & 791 & 18 & 1 & - & 19 & 829 \\
\hline 8 & 8 & 794 & 17 & 1 & - & 17 & 829 \\
\hline
\end{tabular}

1. OA 1, of the 829 words/phrases in question there were seven zeros, 758 responses in Javanese "ngoko", 14 responses in Indonesian and 50 in Osing.

2. OA 2, of the 829 words/phrases in question there were 20 zeros, 757 responses in Javanese "ngoko", 23 responses in Indonesian and 29 in Osing.

3. OA 3, of the 829 words/phrases in question there were 28 zeros, 736 responses in Javanese "ngoko" and 65 responses in Indonesian.

4. OA 4, of the 829 words/phrases in question there were 28 zeros, 732 responses in Javanese "ngoko" and 69 responses in Indonesian.

5. OA 5, of the 829 words/phrases in question there were 22 zeros and 791 responses in Javanese "ngoko" and 16 responses in Indonesian.

6. OA 6 , of the 829 words/phrases in question there were 22 zeros and 791 responses in Javanese "ngoko" and 16 responses in Indonesian.

7. OA 7, of the 829 words/phrases in question there were 19 zeros and 791 responses in Javanese "ngoko", 18 responses in Indonesian and 1 in Javanese "krama" language.

8. OA 8 , of the 829 words/phrases in question there were 17 zeros and 794 responses in Javanese "ngoko", 17 responses in Indonesian and 1 Javanese "krama" language.
9. Based on the grouping it is evident that OA 3 and OA 4 located in Surabaya City have fewer responses in "ngoko" languages than in OA 1, OA 2, OA 5, OA 6, OA 7 and OA 8.

Responses in the Indonesian language in OA 3 and $\mathrm{OA} 4$ are more than the Indonesian language response in OA 1, OA 2, OA 5, OA 6, OA 7.

It is evident that the preservation of Javanese "ngoko" in Banyuwangi, Magetan and Solo is higher than in Surabaya. This may be influenced by various factors, one of which is the geographical factor of Surabaya. The city of Surabaya is the center of the East Java provincial government, therefore it leads to a lot people from various regions migrating to Surabaya hoping to find work. The diversity of people now living in Surabaya City results in more variants of language that may shift the existence of Javanese "ngoko" in Surabaya. The following graph shows the number of Javanese "ngoko" in each OA in Banyuwangi, Surabaya, Magetan, and Solo.

The figure 5 shows the lexical number in each OA in Banyuwangi, Surabaya, Magetan, and Solo which demonstrates the inequality in the numberof Javanese "ngoko" in Surabaya with Javanese "ngoko" in Banyuwangi, Magetan, and Solo. The number of Javanese "ngoko" lexical languages in Magetan and Solo is more than the number of Javanese "ngoko" lexical in Banyuwangi and Surabaya.

The calculation of lexical differences of Javanese "ngoko" in Banyuwangi, Surabaya, 
Figure 5. The number of Javanese "ngoko" Lexical in Banyuwangi, Surabaya, Magetan, and Solo

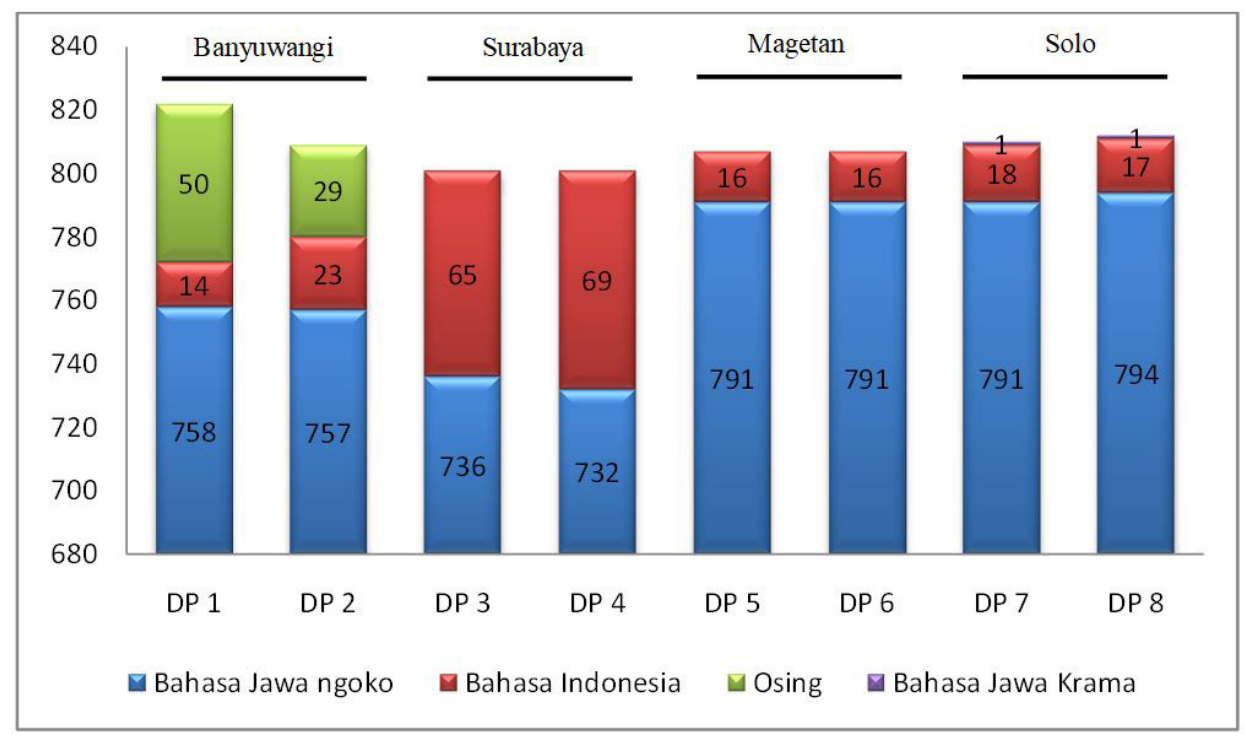

Table 5: Lexical Dialectometry of Javanese "ngoko" in Banyuwangi, Surabaya, Magetan, and Solo

\begin{tabular}{|c|c|c|c|c|}
\hline No. OA & $\begin{array}{c}\text { The Number of } \\
\text { Difference (S) }\end{array}$ & $\begin{array}{c}\text { The Number of } \\
\text { Compared Maps (n) }\end{array}$ & $\begin{array}{c}\text { Word Distance } \\
(\mathbf{d} \%)\end{array}$ & Note(s) \\
\hline $\mathbf{1 - 2}$ & 112 & 405 & $27.65 \%$ & Different utterance \\
\hline $\mathbf{1 - 3}$ & 261 & 405 & $64.44 \%$ & Different dialect \\
\hline $\mathbf{2 - 3}$ & 187 & 405 & $46.17 \%$ & Different subdialect \\
\hline $\mathbf{2 - 4}$ & 215 & 405 & $53.09 \%$ & Different dialect \\
\hline $\mathbf{2 - 6}$ & 151 & 405 & $37.28 \%$ & Different subdialect \\
\hline $\mathbf{3 - 4}$ & 28 & 405 & $6.91 \%$ & No difference \\
\hline $\mathbf{4 - 5}$ & 187 & 405 & $46.17 \%$ & Different subdialect \\
\hline $\mathbf{4 - 6}$ & 185 & 405 & $45.67 \%$ & Different subdialect \\
\hline $\mathbf{4 - 8}$ & 260 & 405 & $64.98 \%$ & Different dialect \\
\hline $\mathbf{5 - 6}$ & 48 & 405 & $11.85 \%$ & No difference \\
\hline $\mathbf{5 - 7}$ & 151 & 405 & $37.28 \%$ & Different subdialect \\
\hline $\mathbf{5 - 8}$ & 148 & 405 & $36.54 \%$ & Different subdialect \\
\hline $\mathbf{6 - 7}$ & 154 & 405 & $38.02 \%$ & Different subdialect \\
\hline $\mathbf{7 - 8}$ & 37 & 405 & $9.16 \%$ & No difference \\
\hline
\end{tabular}

Magetan, and Solo was done by referring to the map of dialectometry triangle and polygon. However, the data showed that not all OAs had Javanese "ngoko" responses to the words presented to them. For example: the human body part TEMBUNI (word no.143) has theresponse [əmbin əmbin], which is only known in OA 7 and OA 8 in Solo, while it is not exist in other OA's. It is because the response [əmbin əmbin] is not used in the daily utterance in each of the (other?)OAs. Of the 829 words/phrases which were asked to the adults in OA 1, OA 2, OA 3, OA 4, OA 5, and OA 6, 405 lexical differences in the Javanese "ngoko" were obtained. The following is the lexical dialectometry calculation of Javanese "ngoko" in Banyuwangi, Surabaya, Magetan, and Solo. 
Based on the lexical dialectometry calculation of Javanese "ngoko" in Banyuwangi, Surabaya, Magetan, and Solo (Table 5), the following division groups were obtained:

1. OA which showed no difference with a percentage of $0 \%-20 \%$ were in OA $3--4$, OA 5--6, OA 7--8.

2. OA which showed the difference in the utterance with a percentage of $21 \%-30 \%$ were in OA 1--2.

3. OAwhich showed the difference in subdialect with a percentage of $31 \%-50 \%$ were in OA 2--3, OA2--6, OA4--5, OA4--6, OA 5--7, OA 5--8 and OA 6--7.

4. OA which showed the difference in dialect with the percentage of $51 \%-80 \%$ were in OA $1--3$, OA 2--4, and OA 4--8.

Figure 6. The Lexical Difference of Javanese "ngoko" in Banyuwangi, Surabaya, Magetan and Solo

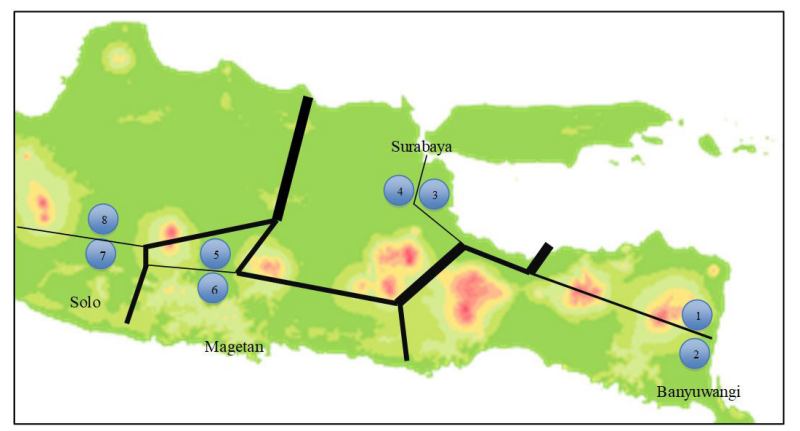

Notes:

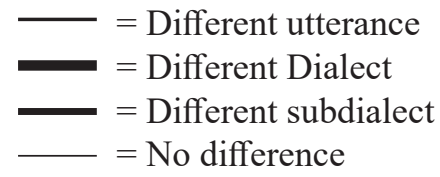

The calculation of lexical difference in Javanese "ngoko" in Banyuwangi, Surabaya, Magetan, and Solo showed no difference in OA 3--4, OA 5--6, OA 7--8. This proves that there is no difference in one region; OA 3--4 represent Surabaya, OA 5--6 represent Magetan and OA 7--8 represent Solo. Utterance differences were found in OA 1--2 which is in the Banyuwangi area. In fact, the suburbs and the central city of Banyuwangi have different utterances because the people in the suburbs of Banyuwangi prefer using Osing language compared to the people in the central city. Subdialect differences in OA 2--3, OA2--6, OA4--5, OA4--6, OA 5--7, OA 5--8 and OA
6--7. OA 1--3, OA 2--4, and OA 4--8 indicated dialect differences. The dialect differences were reflected in three research sites, Banyuwangi, Surabaya and Solo, Accordingly it forms Banyuwangi dialect, Surabaya dialect, and Solo dialect. Figure 6 shows the dialect differences of Javanese "ngoko" in Banyuwangi, Surabaya, Magetan, and Solo.

\section{The Calculation of Total Phonological Differences of Javanese"Ngoko"}

The phonological calculations of Javanese "ngoko" in Banyuwangi, Surabaya, Magetan, and Solo were based on the dialectometry triangle and polygon map. The calculation of phonological differences of Javanese "ngoko" in Banyuwangi, Surabaya, Magetan, and Solo indicates the existence of variant and correspondence. The sign $(\approx)$ indicate the existence of correspondence and the sign ( , ) indicates the variant on the words/phrases in question. Of the 829 words/phrases questioned in OA 1, OA 2, OA 3, OA 4, OA 5, and OA 6, 300 phonological differences were found. Here are the details of phonological differences in Banyuwangi, Surabaya, Magetan, and Solo. (See Table 6)

The number of phonological differences is the quantity when thephonological dialectometry of Javanese "ngoko" in Banyuwangi, Surabaya, Magetan, and Solo is calculated. The number can grow if it involves other differences that contain the same thing. Table 7 shows the phonological calculations of Javanese "ngoko" in Banyuwangi, Surabaya, Magetan, and Solo.

Based on the phonological dialectometry calculation of Javanese "ngoko" in Banyuwangi, Surabaya, Magetan, and Solo the following distribution groups were obtained:

1. OA which showed no difference with a percentage of $0 \%-3 \%$ were in OA 3--4, OA 5--6, OA 5--8, OA 7--8.

2. OA which showed difference of utterance with a percentage of $4 \%$ - $7 \%$ were in OA $1--2$, OA 1--3, OA 2--3, OA2--4, OA2--6, OA4--5, OA 4--6, OA 4--8, OA 5--7 and OA 6--7.

3. OA which showed the difference of subdialect with a percentage of $8 \%-11 \%$ was not found.

4. OA which showed the difference of dialect with a percentage of $12 \%-16 \%$ was not found.

Calculation of phonological differences of Javanese "ngoko" in Banyuwangi, Surabaya, Magetan, and Solo showed utterance difference inOA 1--2, OA 
Table 6. The Details of Phonological Difference of Javanese "ngoko" in Banyuwangi, Surabaya, Magetan, and Solo

\begin{tabular}{|c|c|c|c|c|}
\hline No. & $\begin{array}{c}\text { The Detail of Phonological } \\
\text { Difference }\end{array}$ & \multicolumn{2}{|c|}{ Example } & \multirow{2}{*}{$\begin{array}{c}\text { Total } \\
2 \\
\end{array}$} \\
\hline 1 & epentesis [a] & {$[$ təlau $] \approx[$ təlu $]$} & three & \\
\hline 2 & epentesis [y] palatisasi & [udyan] $\approx$ [udan] & rain & 10 \\
\hline \multirow{4}{*}{3} & 4 syllable $\approx 3$ syllable & [səbagian] $\approx$ [bagian] & part & 2 \\
\hline & 4 syllable $\sim 2$ syllable & [cumi cumi] $\sim$ [cumi] & squid & 1 \\
\hline & 3 syllable $\approx 2$ syllable & {$[$ kəbaya $] \approx[$ baya $]$} & kebaya dress & 10 \\
\hline & 2 syllable $\approx 1$ syllable & {$[$ țole $] \approx[\mathrm{le}]$} & son & 8 \\
\hline 4 & $\ddot{\mathrm{O}} \approx \wedge$ & {$[\mathrm{ibuÖ}] \approx[\mathrm{ibu}]$} & mother & 7 \\
\hline 5 & $\mathrm{~b} \sim^{\wedge}$ & {$[\mathrm{mbah}$ buyUt $] \sim[\mathrm{mbah}$ uyUt $]$} & grandparents & 1 \\
\hline 6 & $\mathrm{~h} \approx \wedge$ & [yiduh $] \approx[$ yidu $]$ & spit & 3 \\
\hline 7 & $1 \approx \wedge$ & [gəraji] $\approx$ [graji] & saw & 15 \\
\hline 8 & $\mathrm{w} \approx \wedge$ & {$[$ wulu $] \approx[\mathrm{ulu}]$} & feather & 4 \\
\hline 9 & $\mathrm{~m} \approx \wedge$ & {$[$ mbale $] \approx[$ bale $]$} & living room & 12 \\
\hline 10 & $\mathrm{~g} \approx \ddot{\mathrm{O}}$ & $\begin{array}{c}{[\text { munəg munəg }] \approx[\text { munəÖ }} \\
\text { munəÖ] }]\end{array}$ & nauseous & 7 \\
\hline 11 & $\mathrm{t} \approx \mathrm{O}$ & [ygolEti] $\approx$ [ygolEÖi] & seek & 2 \\
\hline 12 & $\mathrm{~m} \sim \mathrm{W}$ & [mวwว] [wวwว] & burning charchoal & 1 \\
\hline 13 & $\mathrm{t} \sim \mathrm{d}$ & [gəntEn] [gənḍEg] & rooftop & 1 \\
\hline 14 & $\mathrm{c} \sim \mathrm{j}$ & [cənḍelo] [jənḍelo] & window & 1 \\
\hline 15 & $\mathrm{t} \approx t, \mathrm{t}$ & [gənton] $\approx$ [gənțoy] & large earthenware bowl for water & 4 \\
\hline 16 & $\mathrm{~b} \approx \mathrm{w}$ & [bakUl gəḍe] $\approx$ [wakUl gəḍe] & big rice bowl & 9 \\
\hline 17 & $\mathrm{~b} \sim \mathrm{m}$ & [bəsəsəgan] [məsəsəgan] & $s o b$ & 1 \\
\hline \multirow{16}{*}{18} & $\mathrm{a} \sim \mathrm{o}$ & {$[\mathrm{akEh}] \sim[\mathrm{okEh}]$} & many & 1 \\
\hline & $\mathrm{a} \approx \varepsilon$ & {$[$ kari $] \approx[$ kEri $]$} & let out & 3 \\
\hline & $\mathrm{a} \approx \mathrm{e}$ & [nay yarəp] $\approx$ [ney yarəp] & in front of & 4 \\
\hline & $\mathrm{a} \approx 0$ & {$[\tilde{\eta}$ akวt $] \approx[\tilde{\eta} \supset k \supset t]$} & bite & 7 \\
\hline & $\mathrm{a} \approx 1$ & {$[\operatorname{lamt} \mathrm{r}] \mathrm{H}[1 \backslash \mathrm{mt} \mathrm{r}]$} & $\begin{array}{c}\text { bean with pungent odor, widely } \\
\text { eaten raw and cooked }\end{array}$ & 6 \\
\hline & $\mathrm{a} \sim \mathrm{i}$ & [abay] [abin] & red & 1 \\
\hline & $\mathrm{i} \approx \backslash$ & {$[\mathrm{cibl} \supset \ddot{O}] \approx[\mathrm{c} \backslash \mathrm{bl} \mathrm{OO}]$} & fall & 3 \\
\hline & $\mathrm{i} \sim \mathrm{u}$ & {$[$ krini $] \sim[$ kruyu $]$} & hear & 1 \\
\hline & $\mathrm{i} \approx \mathrm{e}$ & [gəḍi] $\approx$ [gəḍe] & big & 28 \\
\hline & $\mathrm{i} \sim \mathcal{E}$ & [isuÖ] [ [EsuÖ] & morning & 1 \\
\hline & $\mathrm{u} \sim \mathrm{U}$ & [baÖ adus] [baÖ adUs] & bath up & 1 \\
\hline & $\mathrm{u} \sim \mathrm{o}$ & {$[$ kursi $] \sim[$ korsi $]$} & chair & 1 \\
\hline & $\mathrm{u} \approx \mathrm{o}$ & {$[$ kunci $] \approx[$ konci $]$} & key & 33 \\
\hline & $\mathrm{u} \approx \backslash$ & 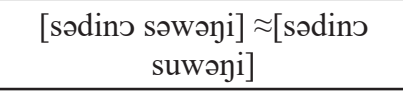 & a day and a night & 3 \\
\hline & $\mathrm{e} \sim \mathrm{o}$ & [nḍeÖ kene] [ndoÖ kene] & here & 1 \\
\hline & $\mathrm{e} \approx \mathcal{E}$ & {$[$ teron $] \approx[$ tEron $]$} & eggplant & 2 \\
\hline 19 & etc & {$[$ sawEn] $\approx[$ sawi $]$} & mustard green & 103 \\
\hline \multicolumn{3}{|c|}{ Total Compared Maps } & & 300 \\
\hline
\end{tabular}


Table 7: Phonological Difference of Javanese "ngoko" in Banyuwangi, Surabaya, Magetan, and Solo

\begin{tabular}{|c|c|c|c|c|}
\hline No. OA & $\begin{array}{c}\text { The Number of } \\
\text { Difference (S) }\end{array}$ & $\begin{array}{c}\text { The Number of } \\
\text { Compared Maps (n) }\end{array}$ & $\begin{array}{c}\text { Word Distance } \\
(\mathbf{d} \%)\end{array}$ & Note(s) \\
\hline $\mathbf{1 - 2}$ & 11 & 300 & $3.6 \%$ & Different utterance \\
\hline $\mathbf{1 - 3}$ & 17 & 300 & $5.6 \%$ & Different utterance \\
\hline $\mathbf{2 - 3}$ & 11 & 300 & $3.6 \%$ & Different utterance \\
\hline $\mathbf{2 - 4}$ & 15 & 300 & $5 \%$ & Different utterance \\
\hline $\mathbf{2 - 6}$ & 13 & 300 & $4.3 \%$ & Different utterance \\
\hline $\mathbf{3 - 4}$ & 5 & 300 & $1.6 \%$ & No difference \\
\hline $\mathbf{4 - 5}$ & 14 & 300 & $4.6 \%$ & Different utterance \\
\hline $\mathbf{4 - 6}$ & 17 & 300 & $5.6 \%$ & Different utterance \\
\hline $\mathbf{4 - 8}$ & 10 & 300 & $3.3 \%$ & Different utterance \\
\hline $\mathbf{5 - 6}$ & 8 & 300 & $2.6 \%$ & No difference \\
\hline $\mathbf{5 - 7}$ & 10 & 300 & $3.3 \%$ & Different utterance \\
\hline $\mathbf{5 - 8}$ & 9 & 300 & $3 \%$ & No difference \\
\hline $\mathbf{6 - 7}$ & 11 & 300 & $3.6 \%$ & Different utterance \\
\hline $\mathbf{7 - 8}$ & 2 & 300 & $0.6 \%$ & No difference \\
\hline
\end{tabular}

Figure 7. Percentage of Phonological Difference of Javanese "ngoko" in Banyuwangi, Surabaya, Magetan, and Solo

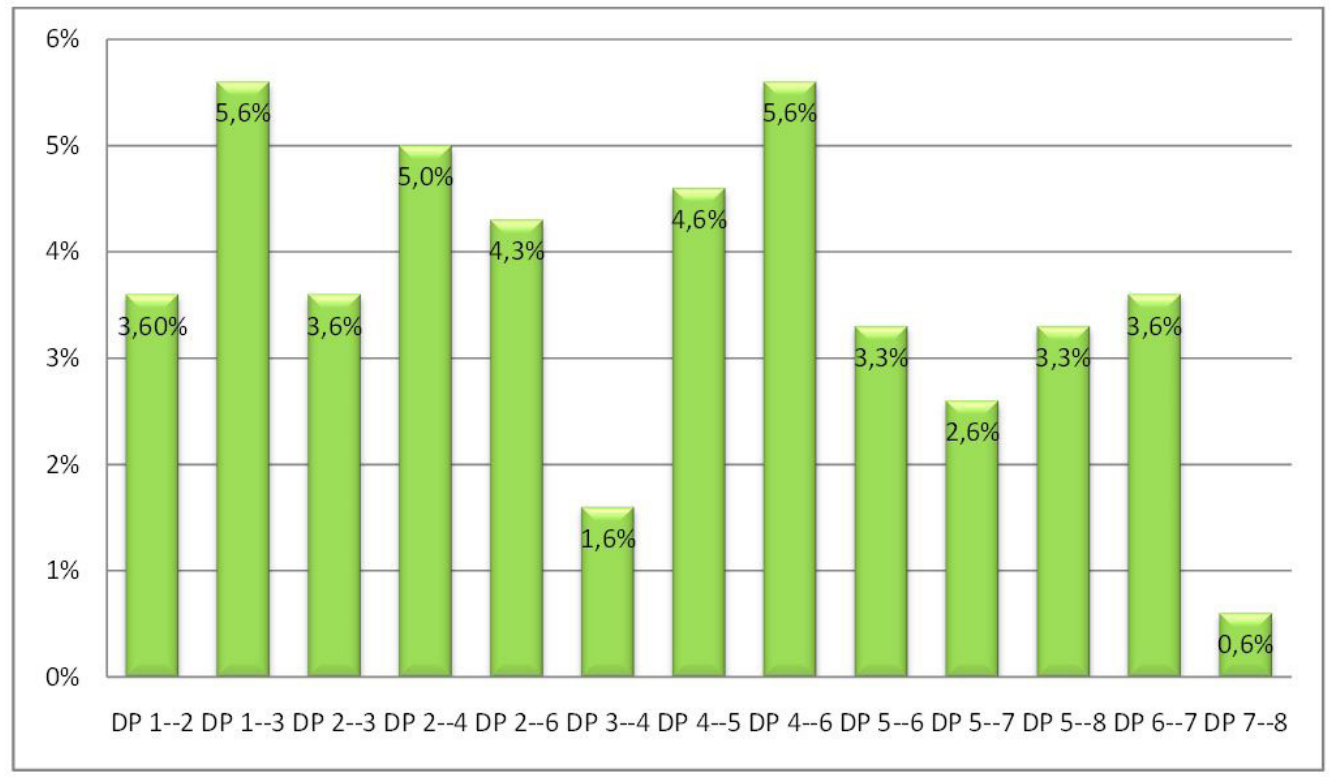

1--3, OA 2--3, OA 2--4, OA 2--6, OA 4--5, OA 4--6, OA 4--8, OA 5--7 and OA 6--7. This proved that there were a lot of phonological similarities of Javanese "ngoko" among OAs. The following graph shows the phonological differences of Javanese "ngoko" in Banyuwangi, Surabaya, Magetan, and Solo.
Phonological differences in OA 1--2, OA 1-3, OA 2--3, OA 2--4, OA 2--6, OA 4--5, OA 4--6, OA 4--8, OA 5--7 and OA 6--7 showed utterance differences whereas in OA 3--4, OA 5--6, OA 5--8, OA 7--8 showed no difference. The following is a map of phonological differences of Javanese "ngoko" 
in Banyuwangi, Surabaya, Magetan, and Solo which shows the difference in utterance on OAs compared.

Figure 8. Phonological Difference of Javanese "ngoko" in Banyuwangi, Surabaya, Magetan and Solo

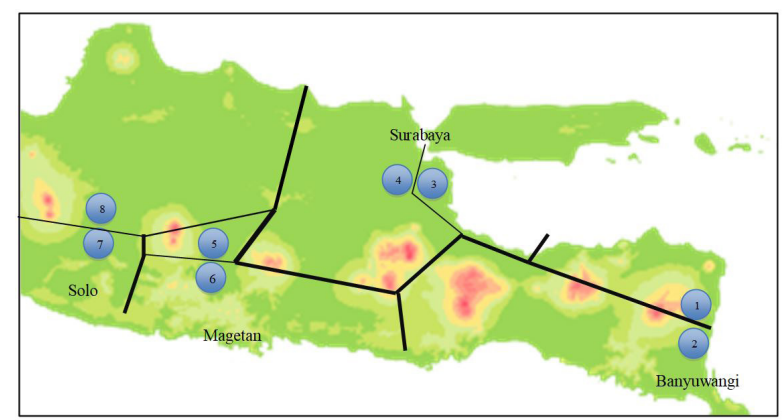

Notes:

$-=$ Different utterance
$=$ No difference

The map of phonological differences of Javanese "ngoko" shows thickening at OA 1--2, OA 1--3, OA 2--3, OA 2--4, OA 2--6, OA 4--5, OA 4--6, OA 4--8, OA 5--7 and OA 6--7 which shows a different utterance borderline among Banyuwangi, Surabaya, Magetan, and Solo. OA 3--4, OA 5--6, OA 5--8, and OA 7--8 do not show any thickening because there is no difference in the OAscompared.

\section{CONCLUSION}

The conclusions of this research is that there are lexical and phonological differences of Javanese "ngoko" in Banyuwangi, Surabaya, Magetan and Solo, namely 1) lexical differences in Javanese "ngoko" in Banyuwangi, Surabaya, Magetan and Solo which resulted in one utterance, two dialects and four subdialects, 2) The phonological differences of Javanese "ngoko" in Banyuwangi, Surabaya, Magetan, and Solo resulted in four utterances.

\section{RECOMMENDATION}

The results of Javanese language research in Banyuwangi, Surabaya, Magetan, and Solo can be used by the local government to make policy in the effort of cultivating and developing the Javanese language in Banyuwangi, Surabaya, Magetan, and Solo. Also, this research is useful in teaching the Javanese language in schools so that the next generation of the nation will not forget the Javanese language. In the field of dialectology, this research can be employed in making the Javanese language map in Banyuwangi, Surabaya, Magetan, and Solo. The Javanese language map is beneficial to: (1) facilitate language reconstruction so as to assist in the field of comparative historical linguistics, (2) localize the concept of Javanese culture as far as the concept is reflected in the word/phrase of Javanese "ngoko", (3) make a prediction map of epidemic spread because the limit of epidemic dissemination is generally in line with the language/dialect limit, and epidemic easily infects people who often make contact. As evidence, WHO has used language maps to predict the epidemic spread.

\section{REFERENCES}

Aliana, Zainul arifin (2003). Bahasa Daerah: Beberapa Topik. Inderalaya: Universitas Sriwijaya.

Aslinda dan Leni Syafyahya (2007). Kedwibahasaan, Dwibahasawan, dan Diglosia. Bandung: Refika Aditama.

Ayatrohaedi (1983). Dialektologi: Sebuah Pengantar. Jakarta: Pusat Pembinaan dan Pengembangan Bahasa, Depdikbud.

Chambers, J. K, dkk. (ed.) (2002). The Handbook of Language Variation and Change. USA: Blackwell Publishing.

Chambers, J. K dan Peter Trudgill (1990). Dialektologi. Terjemahan Annuar Ayub. Kuala Lumpur: Dewan Bahasa dan Pustaka.

Ferguson. C. A. (1959). “Diglossia” dalam Anwars. Dill. Editor 1971. Language Structure and Language Use. Standford. California: Standford University Press.

Grosjean, Francois (1982). Life with Two Languages. Cambridge: Harvard University Press.

Kisyani-Laksono (1998). Isolek Bahasa Jawa di Keduwung, Tengger dalam Linguistik Indonesia: Masyarakat Linguistik Indonesia. Jakarta.

Kisyani-Laksono (2000). Isolek Bahasa Jawa di Tuban dan Bojonegoro. Verba, Februari 2000. Surabaya: FBS, Unesa.

Kisyani-Laksono (2004). "Identifikasi Kosakata Krama dalam Bahasa Jawa Dialek Jawa Timur dan Dialek Using” in Masyarakat Linguistik Indonesia. Jakarta: MLI in collaboration with Yayasan Obor Indonesia.

Kisyani-Laksono (2004). Bahasa Jawa di Jawa Timur Bagian Utara dan Blambangan (Kajian Dialektologis). Jakarta: Pusat Bahasa Departemen Pendidikan Nasional.

Kisyani-Laksono dan Agusniar (2009). Dialektologi. 
Surabaya: Unesa University Press.

Kurniati, Endang dan Mardikantoro, Hari Bakti (2010). Pola Variasi Bahasa Jawa (Kajian Sosiodialektologi pada Masyarakat Tutur di Jawa Tengah. Humaniora, 22, 273-284.

Lauder, Multamia Retno Mayekti Tawangsih (1993). Pemetaan dan Distribusi Bahasa-Bahasa di Tangerang. Jakarta: Pusat Pembinaan dan Pengembangan Bahasa.

Mahsun (1995). Dialektologi Diakronis. Yogyakarta: Gadjah Mada University Press.

Mahsum (2005). Metode Penelitian Bahasa. Yogyakarta: Grasindo Jaya.

Meillet, Antoine (1970). The Comparative Method in Historical Linguistics. Trans. Gordon B. Ford. Paris: Libraire Honore Champion.

Meillet, Antoine (1970). The Reconstruction of ProtoMalayo-Javanic.S-Gravenhage: Martinus Nijhoff.

Petyt, K. M. (1980). The Study of Dialect: An Introduction to Dialectology. London: Andre Deutsch.
Poedjosoedarmo, Supomo (1979). Tingkat Tutur Masyarakat Jawa. Widya Parwa 22 Yogyakarta: Balai Penelitian Bahasa Yogyakarta.

Romaine, Suzane (1989). Bilingualism. New York: Basil Blackwell Ltd.

Toha, Muhammad (2013). Isolek-Isolek di Kabupaten Aceh Tamiang Provinsi Aceh: Kajian Dialektologi. Madah, 4(1), 58-69. Retrieved from ejurnalbalaibahasa.id/index.php/madah/article/ download/556/334

Sasangka, Sry Satriya Tjatur Wisnu (2011). Paramasastra Gagrag Anyar Basa Jawa. Jakarta: Yayasan Paramalingua.

Sudaryanto (1992). Metode dan Teknik Pengumpulan Data. Yogyakarta: Gajah Mada Unipress.

Sumarsono (1993). Metode dan Aneka Teknik Analisis Bahasa: Pengantar Penelitian Wahana Kebudayaan secara Linguistik. Yogyakarta: Duta Wacana University Press.

Sutardi, Tedi (2007). Mengungkap keberagaman Budaya. Bahasa, dialek, dan tradisi lisan. Bandung: PT. Setia Purna Inves. 